\title{
Schiff base SH11 with tuberculostatic and radical scavenging activities against INH-induced oxidative hepatic damage
}

\author{
Nedyalka Georgieva $^{1}$, Zvezdelina Yaneva $^{1}$, Galina Nikolova $^{2}$, Svetlana Simova $^{3}$ \\ ${ }^{1}$ Department of Pharmacology, Animal Physiology and Physiological Chemistry, Faculty of Veterinary Medicine, Trakia University, \\ Students Campus, Stara Zagora, Bulgaria \\ ${ }^{2}$ Department of Medical Chemistry and Biochemistry, Faculty of Medicine, Trakia University, Stara Zagora, Bulgaria \\ ${ }^{3}$ Institute of Organic Chemistry, Bulgarian Academy of Sciences, Sofia, Bulgaria \\ Email: ${ }^{*}$ vvgeorgieva@,vmf.uni-sz.bg
}

Received 8 August 2012; revised 11 September 2012; accepted 16 October 2012

\begin{abstract}
By in vitro visible electron paramagnetic resonance (EPR) spectrophotometry method we demonstrated that N-isonicotinoyl-N'-(3-etoxy-2-hydroxybenzaldehyd) hydrazone (SH11) exhibits radical scavenging activity (SSA). Malondialdehyde (MDA) in mice treated with INH was increased $(2.578 \pm 0.349 \mu \mathrm{M}$ vs. $2.024 \pm 0.164 \mu \mathrm{M}, \mathrm{p}<0.001$ ), while both superoxide dismutase (SOD) $\left(1.583 \pm 0.562 \mathrm{U}_{\text {SOD }} / \mathrm{mg}\right.$ Pr vs. 2.273 $\left.\pm 0.317 \mathrm{U}_{\mathrm{SOD}} / \mathrm{mg} \mathrm{Pr}, \mathrm{p}<0.05\right)$ and catalase (CAT) $\left(30.176 \pm 7.300 \mathrm{U}_{\mathrm{CAT}} / \mathrm{mg}\right.$ Pr, vs. $47.070 \pm 16.490$ $\left.\mathrm{U}_{\mathrm{CAT}} / \mathbf{m g} \operatorname{Pr}, \mathbf{p}<\mathbf{0 . 0 5}\right)$ were decreased, compared to the untreated controls. The combination INH + SH11 $(30 \mathrm{mg} / \mathrm{kg} \mathrm{p.o.}$ ) showed reduced levels of MDA, compared to the INH-treated (mean $2.291 \pm 0.025 \mu \mathrm{M}$ than $2.578 \pm 0.349, p<0.05)$. The combination with the lowest reduction of SOD compared to the controls was $151 \mathrm{mg} / \mathrm{kg}$ i.p. INH $+30 \mathrm{mg} / \mathrm{kg}$ p.o. SH11, but there was a significant difference in SOD activities between the group treated with this combination and the untreated controls $(p<0.05)$. The most effective combination, with CAT levels, close to the controls was $151 \mathrm{mg} / \mathrm{kg}$ i.p. INH + $30 \mathrm{mg} / \mathrm{kg}$ p.o. SH11.
\end{abstract}

Keywords: INH; Schiff Base; Tuberculosis; EPR; Lipid Peroxidation; Antioxidant Enzymes

\section{INTRODUCTION}

Isoniazid (INH) is a first-line medication used in the treatment of infections caused by Mycobacterium tuberculosis [1] and is also used for prophylactic treatment of HIV-positive patients that are at high risk to becoming infected with tuberculosis [2]. However, it has a serious

\footnotetext{
"Corresponding author.
}

limitation of being hepatotoxic [3]. Despite the significant success in the chemotherapy of the tuberculosis, the exploration of new, more active and less toxic biologically active chemical compounds is still continuing. Isonicotinoylhydrazones are compounds structurally related to isoniazid and have antibacterial and antimycobacterial activities $[4,5]$.

However, previous our results have demonstrated in vitro tuberculostatic activity against Mycobacterium tuberculosis strain $\mathrm{H}_{37} \mathrm{Rv}$-London (Minimum inhibitory concentrations (MIC) $-0.070 \mu \mathrm{M}$ ) and low toxicity (lethal dose $\mathrm{LD}_{50}-1012$ p.o. $\mathrm{mg} / \mathrm{kg}$ ) of N-isonicotinoylN'-(3-etoxy-2-hydroxybenzaldehyde)hydrazone (SH11) analogs of the antituberculosis drug isoniazid [5], and hepatoprotective effect of N-isonicotinoyl-N'-(3,5-dichloro-2-hydroxybenzal)hydrazone (SH7) against chronic isoniazid toxicity [6].

Therefore, the aim of the present study was to determine whether recently synthesized Schiff Base SH11 with tuberculostatic activity, prevents isoniazid-induced oxidative hepatic damage and exhibits radical scavenging activity. For this purpose we investigated the radical scavenging activity of SH8 by direct electron paramagnetic resonance (EPR) spectroscopy, the levels of lipid peroxidation products (MDA) and both the activities of the antioxidant enzymes superoxide dismutase (SOD) and catalase (CAT) from liver homogenates of mice treated with INH and INH in combinations with SH11 or vitamin A.

\section{MATERIALS AND METHODS}

\subsection{Compounds Tested}

N-isonicotinoyl-N'-(3-etoxy-2-hydroxybenzaldehyde)hy drazone-Schiff Base SH11, was synthesized according to method of Varbanova and Georgieva [7]. SH11 was obtained by condensing isonicotinoylhydrazide and 3- 
etoxy-2-hydroxybenzaldehyde after having been boiled for several minutes in ethanol (Figure 1).

The test compound was dissolved in dimethylsulfoxide (DMSO)/phosphate buffered saline (PBS: $10 \mathrm{mM}$ phosphate, $120 \mathrm{mM} \mathrm{NaCl}, 2.7 \mathrm{mM} \mathrm{KCl}, \mathrm{pH}$ 7.4) (1:10 $v / v)$.

\subsection{Sample Analysis}

SH11 was purified by recrystallization in organic solvent and characterized by the melting point, evaluated by Kofler microscope. Nitrogen, carbon and hydrogen were determined by element analysis.

\subsection{Determination of SH11 Structure by ${ }^{1} \mathrm{H}$ NMR and ${ }^{13} \mathrm{C}$ NMR Spectra}

${ }^{1} \mathrm{H}$ NMR and ${ }^{13} \mathrm{C}$ NMR spectra were recorded in DMSOd6 at $600.13 \mathrm{MHz}$ and $62.9 \mathrm{MHz}$ on Bruker AVII +600 and Bruker DRX spectrometer. The chemical shift values are reported in $\delta$ units and the down field from tetramethylsilane, recalculated from the solvent signals at 2.50 and $39.50 \mathrm{ppm}$.

\subsection{Direct Electron Paramagnetic Resonance (EPR) Spectroscopy on Powdered and Solution Forms of SH11}

All EPR measurements were performed at room temperature on an X-band EMX ${ }^{\text {micro }}$, spectrometer Bruker, Germany, equipped with standard resonator. All EPR experiments were carried out in triplicate. Spectral processing was performed using Bruker WIN-EPR and Simphonia software. By a direct EPR spectroscopy an EPR singlet signal was registered in powdered and solution forms of SH11. Quartz capillaries were used as sample tubes. Sample tubes were filled with either powdered form or $0.2 \mathrm{M}$ solution of SH11 in dimethyl sulfoxide (DMSO) and placed in the EPR microwave cavity. The EPR spectra of SH11 in both forms were recorded at the following spectrometer settings: receiver gain $2 \times 10^{3}$, power $1.64 \mathrm{~mW}$, center field $3513.50 \mathrm{G}$, sweep width 200 $\mathrm{G}$, time constant $163.84 \mathrm{~ms}$, sweep time $61.44 \mathrm{~s}$, modulation amplitude $10 \mathrm{G}, 5$ scans per sample.

\subsection{Animal Studies and Treatment Schedules}

This study was carried out on white healthy mice (18 $22 \mathrm{~g}$ body weight) divided into four groups of 6 animals each. The animals were housed in plastic cages, fed a normal laboratory diet and water ad libitum. All mice were treated with solution of INH and SH11 or vitamin $\mathrm{A}$ in different combinations in accordance with the routine methods described in the literature [8] with slight modifications. Briefly, four hours after administration of the drugs mice were sacrificed by cervical decapitation. Livers were removed and kept on ice until homogenization on the same day. The samples were first washed with deionized water to separate blood and then homogenized. After centrifugation $20 \mathrm{~min}$ at $2000 \mathrm{~g}$, the upper layer was removed for determination of the amount of protein [9] and diluted with PBS (1:10) $(\mathrm{pH}=7.4)$. The homogenates were extracted with ethanol/chloroform to eliminate lipids, which would have interfered with the measurement of SOD and CAT activity.

\subsection{Estimation of Products of Lipid Peroxidation}

Basal levels of lipid peroxidation as indicated by thiobarbituric acid-reactive substances (TBARS) were determined using the thiobarbituiric acid method, which measures the MDA [10]. In the TBARS assay $1 \mathrm{~mL}$ of the supernatant, $1 \mathrm{~mL}$ of normal saline and $1 \mathrm{~mL}$ of $25 \%$ trichloro-acetic acid were mixed and centrifuged at 2000 $g$ for 20 minutes. One $\mathrm{mL}$ of protein free supernatant was taken, mixed with $0.25 \mathrm{~mL}$ of $1 \%$ thiobarbituric acid and boiled $1 \mathrm{~h}$ at $95^{\circ} \mathrm{C}$. After cooling the absorbance of the resulting pink color was determined spectrophotometrically at $532 \mathrm{~nm}$.

\subsection{Measurement of Antioxidant Enzymes Activities}

\subsubsection{SOD Activity}

SOD was determined according to Sun et al. [11] with minor modification. Xanthine/xanthine-oxidase produced $\left(\mathrm{O}_{2}^{--}\right)_{\mathrm{x}}$ reduce nitroblue tetrazolium (NBT) to formazan, which can be assessed spectrophotometrically at $560 \mathrm{~nm}$. SOD competes with NBT for the dismutation of $\left(\mathrm{O}_{2}^{--}\right)_{\mathrm{x}}$

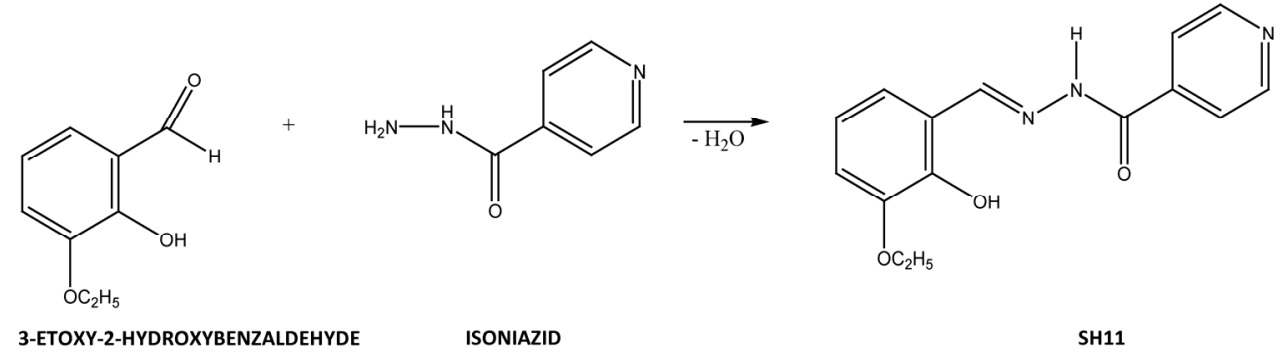

Figure 1. Scheme of the reaction for synthesis of N-isonicotinoyl-N'-(3-etoxy-2-hydroxybenzal)hydrazone. 
and inhibits its reduction. The total SOD activity is expressed in units/mg of protein (U/mg Pr), where one unit is equivalent to the SOD activity that causes 50\% inhibition of the reaction rate without SOD.

\subsubsection{CAT Activity}

The assay of CAT activity was determined by a method according to Beers and Sizer [12] with minor modification. $30 \mathrm{mM} \mathrm{H} \mathrm{H}_{2} \mathrm{O}_{2}$ was used as a substrate and the decrease in $\mathrm{H}_{2} \mathrm{O}_{2}$ concentration at $22^{\circ} \mathrm{C}$ in a phosphate buffer (50 mM, pH 7.0) was followed spectroscopically at $240 \mathrm{~nm}$ for $1 \mathrm{~min}$. The activity of the enzyme was expressed in units per $\mathrm{mg}$ of protein $(\mathrm{U} / \mathrm{mg} \mathrm{Pr})$ and 1 unit equals the amount of an enzyme that degrades $1 \mathrm{M} \mathrm{H}_{2} \mathrm{O}_{2}$ per minute.

\subsection{Statistical Analysis}

The data were statistically processed by ANOVA. All results are presented as mean \pm SEM.

\section{RESULTS}

The simple analysis of compound SH11 with empirical formula $\mathrm{C}_{15} \mathrm{H}_{15} \mathrm{~N}_{3} \mathrm{O}_{3}$ was shown:

C, \%: calculated-63.15, found-62.80;

$\mathbf{H}, \%$ : calculated -5.30 , found -5.48 ;

$\mathbf{N}, \%$ : calculated-14.73, found- 15.02 .

The Carbon spectrum $\left({ }^{13} \mathrm{C}\right.$ NMR) of SH11 was shown:
${ }^{13} \mathrm{C}$ NMR (63 MHz, $\left.\mathrm{CDCl}_{3}\right) \delta 161.27(\mathrm{C}), 150.34(2 \mathrm{CH})$, $149.01(\mathrm{CH}), 147.50(\mathrm{C}), 147.08(\mathrm{C}), 139.96(\mathrm{C}), 121.46$ $(2 \mathrm{CH}), 120.66(\mathrm{CH}), 119.11(\mathrm{CH}), 118.97(\mathrm{C}), 115.38$ $(\mathrm{CH}), 64.14\left(\mathrm{CH}_{2}\right), 39.50$ (DMSO-d6), $14.68\left(\mathrm{CH}_{3}\right)$, Figure 2.

The Proton spectrum $\left({ }^{1} \mathrm{H}\right.$ NMR $)$ of SH11 was showed: ${ }^{1} \mathrm{H}$ NMR (600.13 MHz, DMSO-d6) $\delta 12.29$ (s, 1H), 10.70 $(\mathrm{s}, 1 \mathrm{H}), 8.80(\mathrm{~m}, 2 \mathrm{H}), 8.70(\mathrm{~s}, 1 \mathrm{H}), 7.86(\mathrm{~m}, 2 \mathrm{H}), 7.19(\mathrm{dd}$, $J=7.8,1.3 \mathrm{~Hz}, 1 \mathrm{H}), 7.03(\mathrm{dd}, J=7.9,1.2 \mathrm{~Hz}, 1 \mathrm{H}), 6.85(\mathrm{t}$, $J=7.9 \mathrm{~Hz}, 1 \mathrm{H}), 4.07(\mathrm{~d}, J=7.0 \mathrm{~Hz}, 2 \mathrm{H}), 1.36(\mathrm{t}, J=6.9$ $\mathrm{Hz}, 3 \mathrm{H})$, Figure 3.

The results of ${ }^{13} \mathrm{C}$ NMR (Figure 2), ${ }^{1} \mathrm{H}$ NMR (Figure 3) spectra and simple analysis of SH11 proved the structure of SH 11 with general formula presented in Figure 1.

EPR spectra of powdered and solution forms of SH11 are presented on Figures $\mathbf{4}$ and $\mathbf{5}$.

The results of MDA in liver homogenates of mice are presented in Figure 6. MDA in treated mice with INH at dose $151 \mathrm{mg} / \mathrm{kg}$ i.p. $=\mathrm{LD}_{50}$ were significantly increased, compared to the controls (mean $2.578 \pm 0.349 \mu \mathrm{M}$ than $2.024 \pm 0.164 \mu \mathrm{M}, \mathrm{p}<0.001$, Figure 6). The combination INH + SH11 (30 mg/kg p.o) showed reduced levels of MDA, compared to the INH-treated (mean $2.291 \pm$ $0.025 \mu \mathrm{M}$ than $2.578 \pm 0.349, \mathrm{p}<0.05$, Figure 6). When mice were treated with a combination of INH with vitamin A (i.m.), the levels of MDA were reduced, compared to the INH-treated, but not significantly $(\mathrm{p}>0.05$, Figure 6).

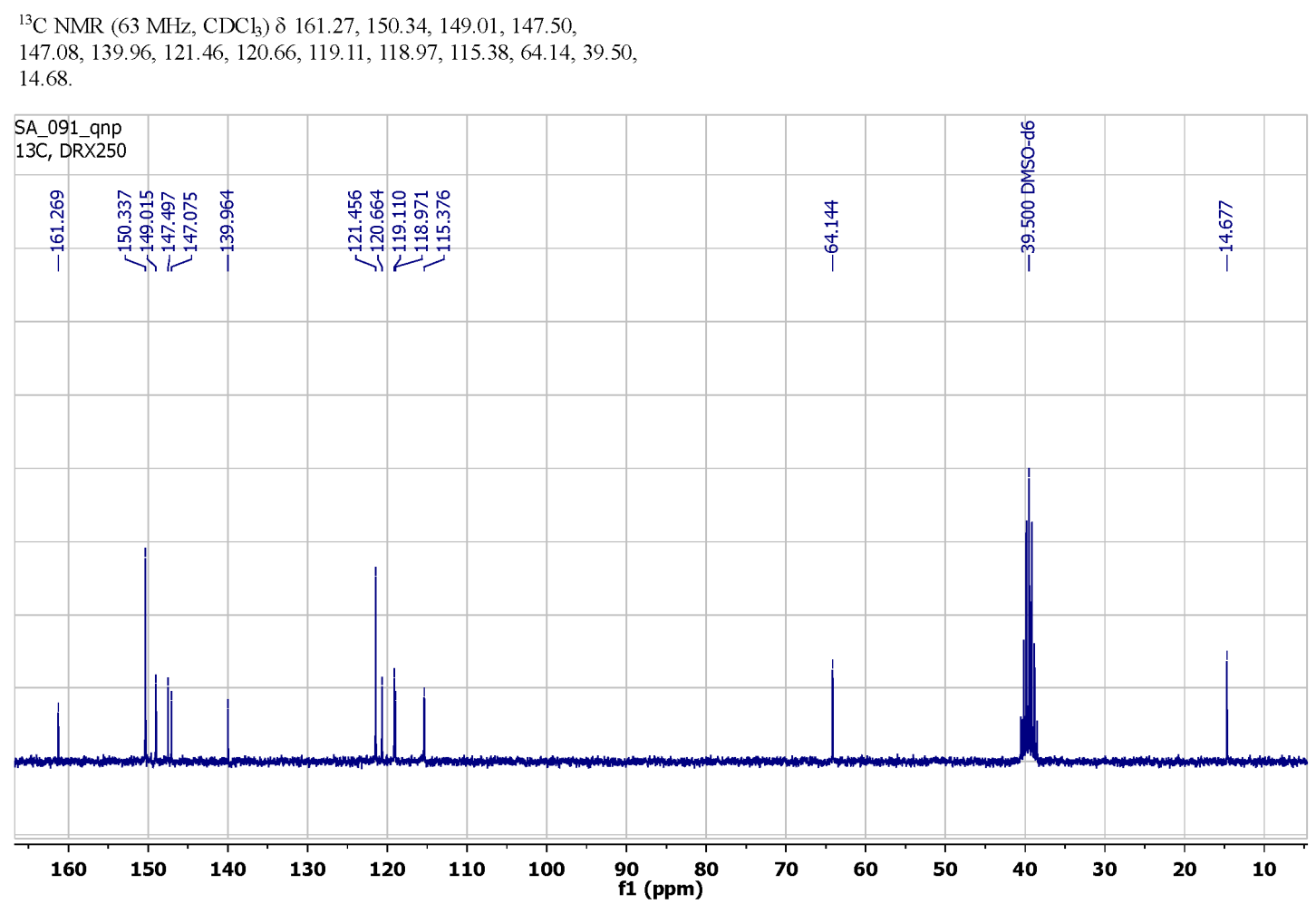

Figure 2. ${ }^{13} \mathrm{C}$ NMR spectra of schiff base SH11. 


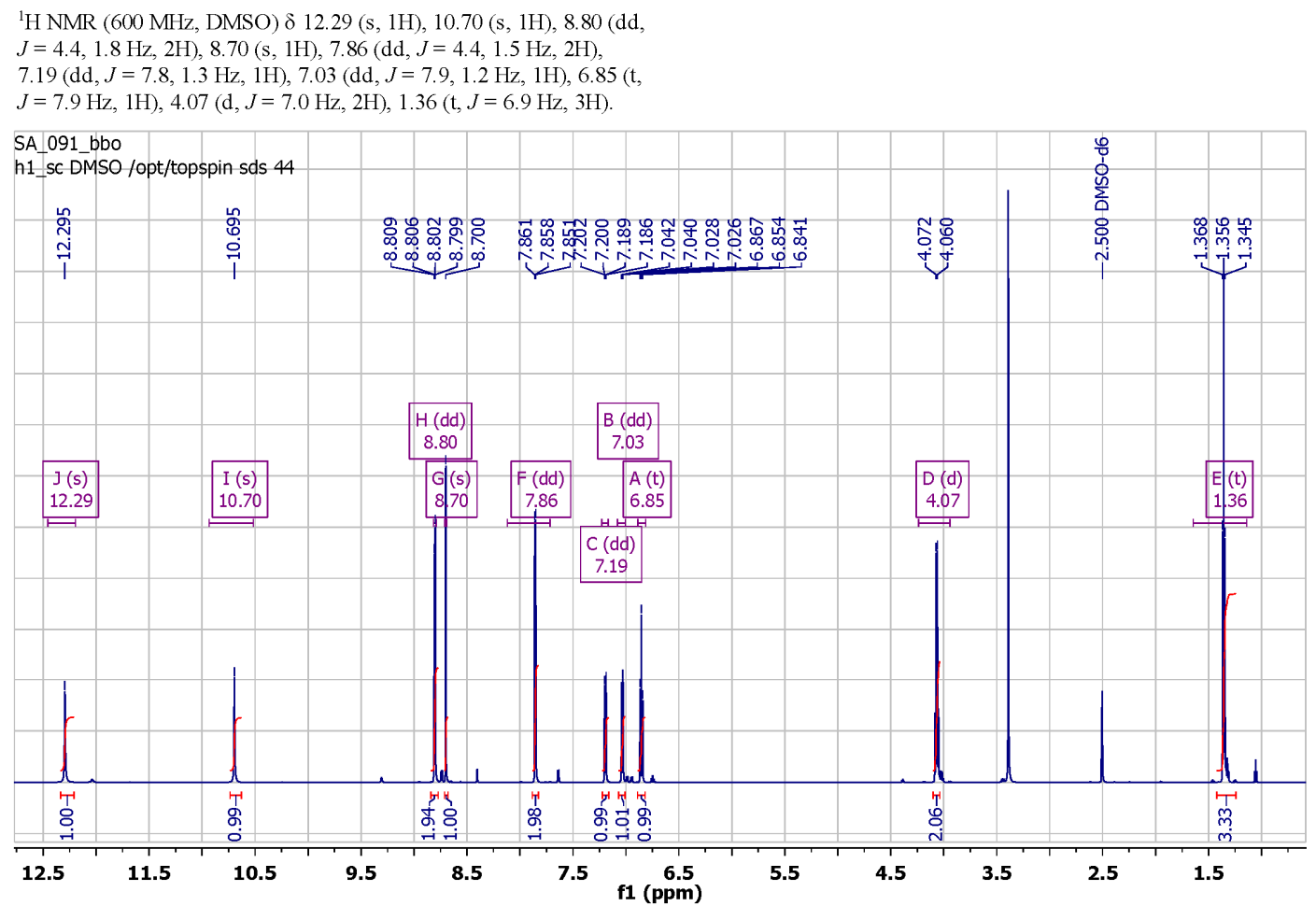

Figure 3. ${ }^{1} \mathrm{H}$ NMR spectra of schiff base SH11.

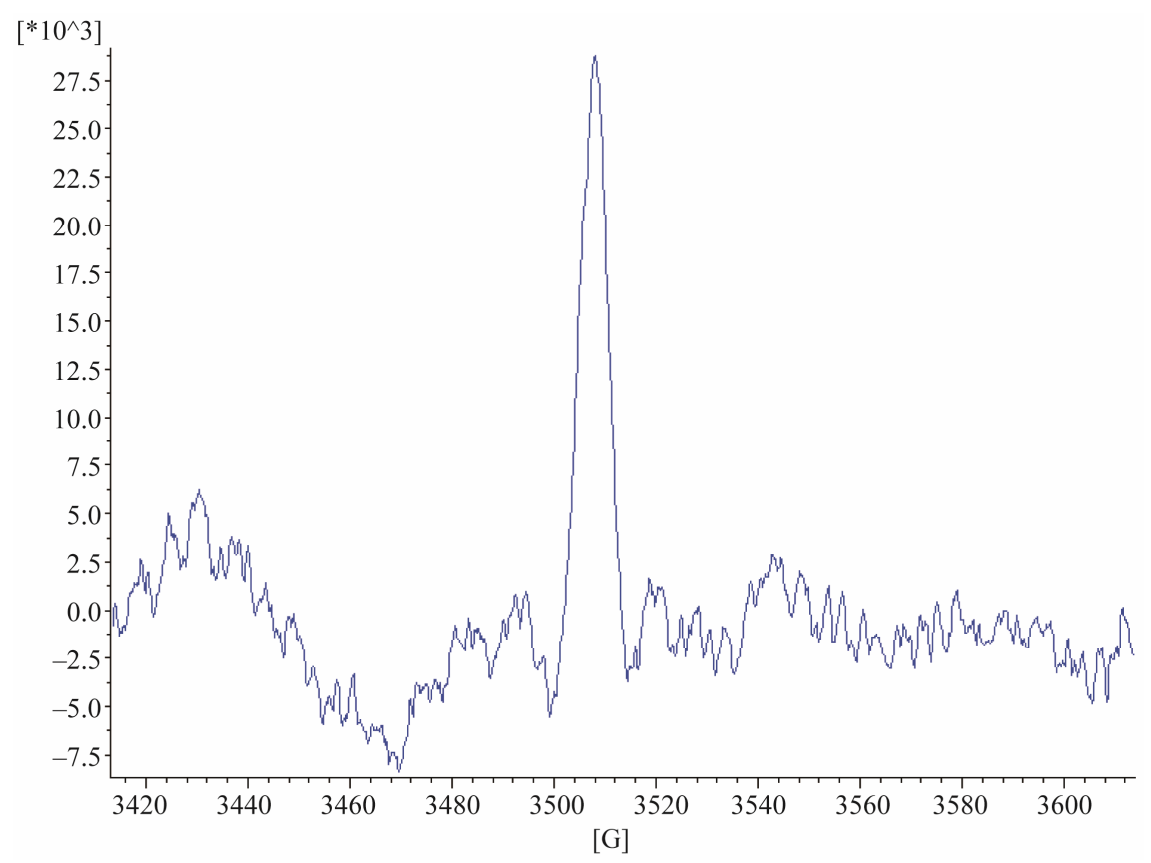

Figure 4. EPR singlet signal in powdered form of SH11.

Antioxidant enzymes SOD and Cat activities in liver homogenates of mice, after treatment with INH alone and in combinations of INH with SH11 or vitamin A are presented in Figures $\mathbf{7}$ and $\mathbf{8}$.

SOD activity in the liver homogenates of mice treated with INH at dose $151 \mathrm{mg} / \mathrm{kg}$ i.p. was statistically signifi- cantly decreased $\left(1.583 \pm 0.562 \mathrm{U}_{\mathrm{SOD}} / \mathrm{mg} \mathrm{Pr}\right)$ than that in the controls $\left(2.273 \pm 0.317 \mathrm{U}_{\mathrm{SOD}} / \mathrm{mg} \operatorname{Pr}\right)(\mathrm{p}<0.05$, Figure 7). The combination with the lowest reduction of SOD compared to the controls was $151 \mathrm{mg} / \mathrm{kg}$ i.p. INH + $30 \mathrm{mg} / \mathrm{kg}$ p.o. SH11, but there was a significant difference in SOD activities between the group treated with 


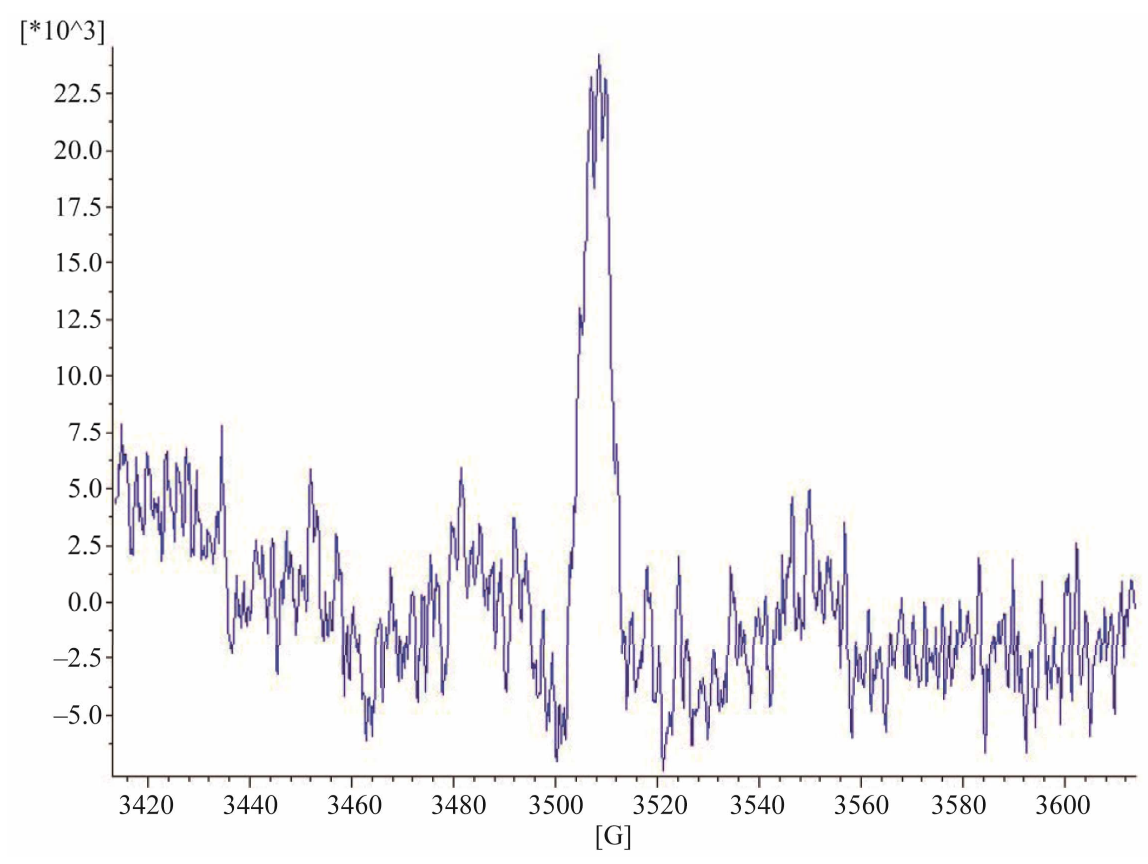

Figure 5. EPR spectra in solution form of SH11.

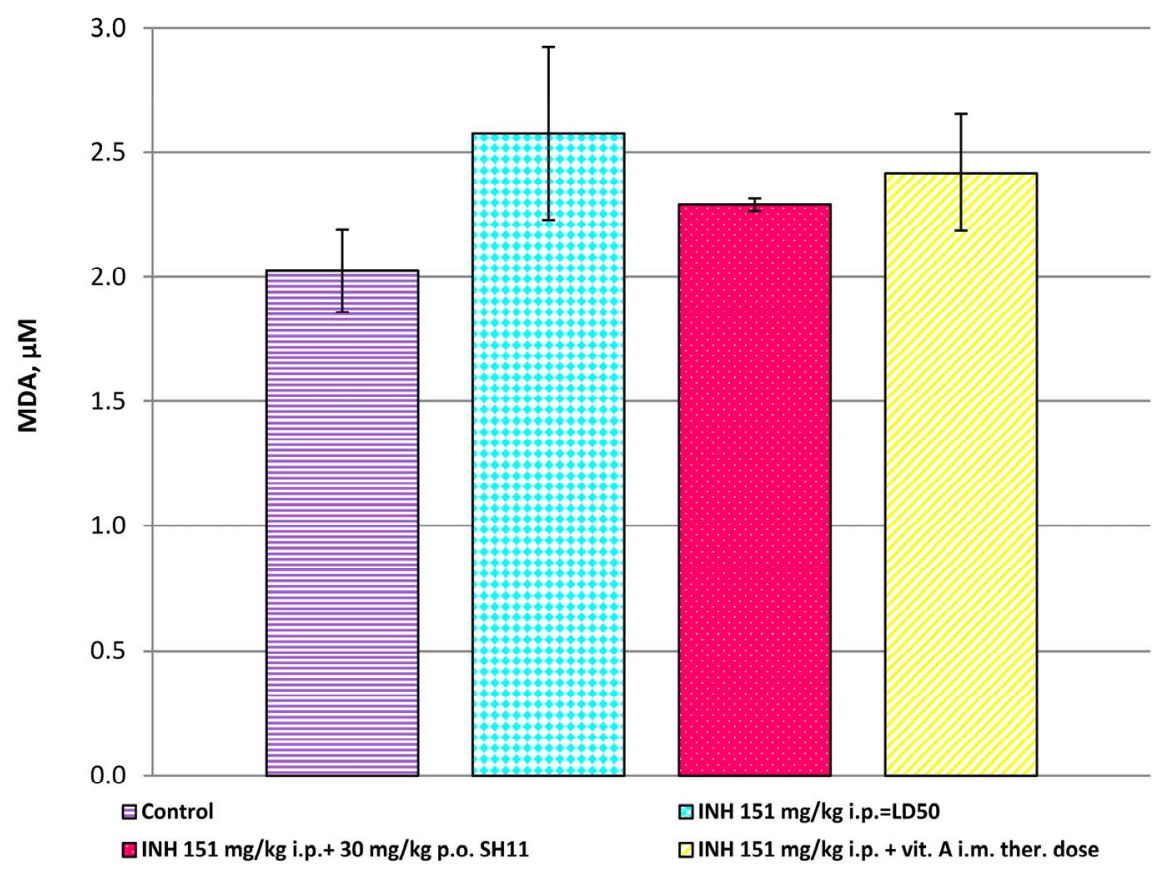

Figure 6. MDA in liver homogenates of mice, after treatment with INH alone and in combinations of INH with SH11 or vitamin A.

this combination and the untreated controls $(\mathrm{p}<0.05$, Figure 7). Significantly greater extend of SOD reduction was established in the liver of mice treated with the combination $\mathrm{INH}+$ vitamin $\mathrm{A}$, as compared to the control group $\left(1.210 \pm 0.061 \mathrm{U}_{\mathrm{SOD}} / \mathrm{mg} \mathrm{Pr}\right.$, vs. $2.273 \pm 0.317$ $\mathrm{U}_{\mathrm{SOD}} / \mathrm{mg} \operatorname{Pr}, \mathrm{p}<0.001$, Figure 7).

When mice were treated with $\mathrm{INH}-151 \mathrm{mg} / \mathrm{kg}$ i.p., the level of CAT activity was statistically decreased com- pared to the controls $\left(30.176 \pm 7.300 \mathrm{U}_{\mathrm{CAT}} / \mathrm{mg} \mathrm{Pr}\right.$, vs. $47.070 \pm 16.490 \mathrm{U}_{\mathrm{CAT}} / \mathrm{mg} \mathrm{Pr}, \mathrm{p}<0.05$, Figure 8). When mice were treated with the combination $151 \mathrm{mg} / \mathrm{kg}$ i.p $\mathrm{INH}+30 \mathrm{mg} / \mathrm{kg}$ p.o. SH11, CAT activity was higher compared to CAT activity of mice, treated with INH alone $\left(39.964 \pm 13.500\right.$ vs. $30.179 \pm 7.300 \mathrm{U}_{\mathrm{CAT}} / \mathrm{mg} \mathrm{Pr}, \mathrm{p}$ $<0.05$, Figure 8). The most effective combination, with CAT levels, close to the controls was $151 \mathrm{mg} / \mathrm{kg}$ i.p. INH 


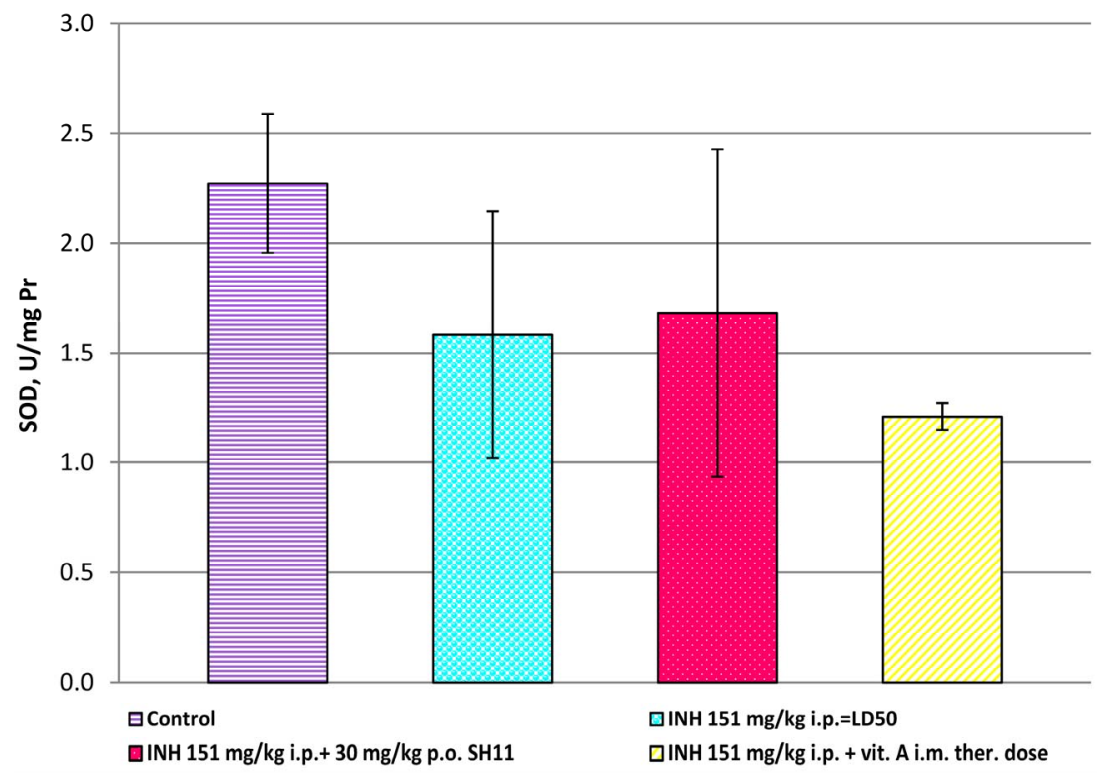

Figure 7. SOD in liver homogenates of mice, after treatment with INH alone and in combinations of INH with SH11 or vitamin A.

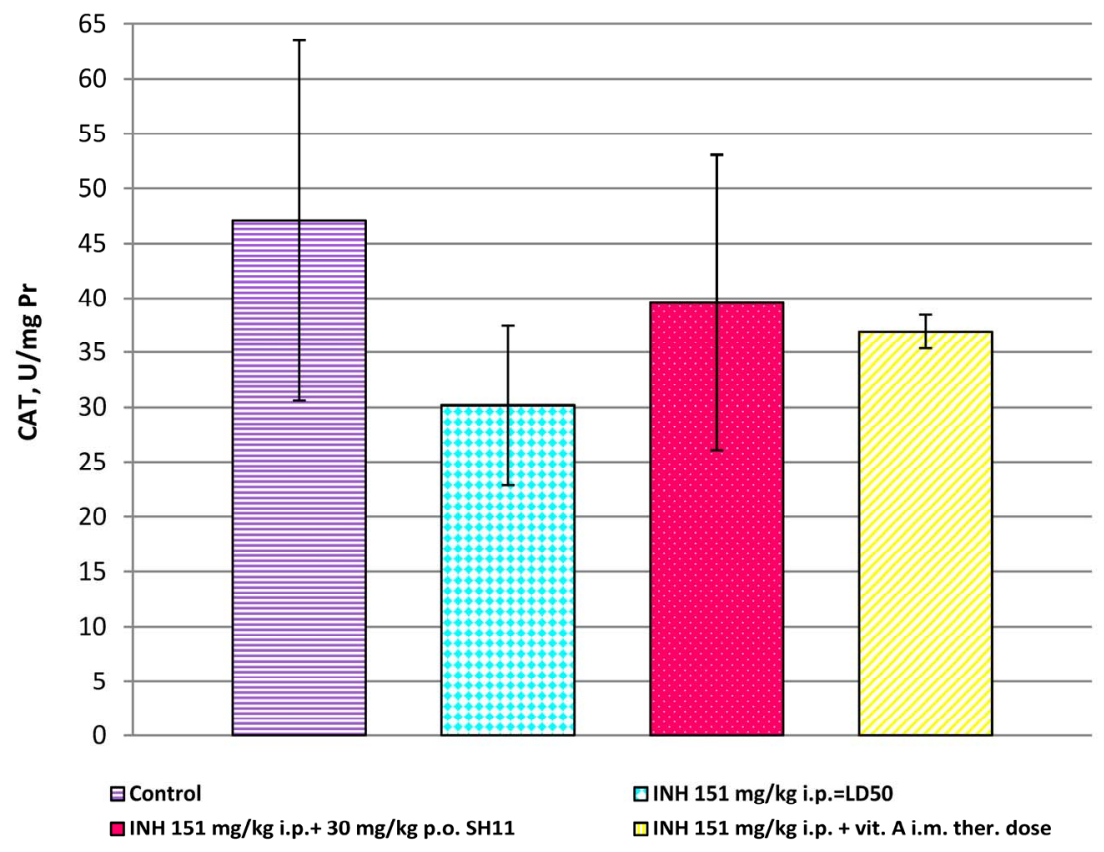

Figure 8. CAT in liver homogenates of mice, after treatment with INH alone and in combinations of INH with SH11 or vitamin A.

$+30 \mathrm{mg} / \mathrm{kg}$ p.o. SH11 (Figure 8). In the liver homogenates of mice, treated with the combination INH and vitamin A were found significantly reduced levels of CAT compared to the controls $\left(36.904 \pm 1.560 \mathrm{U}_{\mathrm{CAT}} / \mathrm{mg}\right.$ Pr vs. $47.070 \pm 16.490 \mathrm{U}_{\mathrm{CAT}} / \mathrm{mg} \operatorname{Pr}, \mathrm{p}<0.001$, Figure 8).

\section{DISCUSSION}

The increased blood MDA concentrations observed in mice treated with INH, were probably related to abnor- mal ROS production. Our results confirmed that liver homogenates of mice treated with INH had high formation of lipid peroxidation products and it is accompanied by decreasing in the activity of the antioxidant defense enzymes SOD and CAT, which was probably related to abnormal ROS production. ROS accumulation is known to induce oxidative stress [28]. The results of the present study showed decreased both SOD and CAT activities in the liver homogenates of mice treated with 
INH, compared to the controls (Figures 7 and 8).

Superoxide dismutase is an enzyme participating in the systemic antioxidant defense for the dismutation of superoxide to hydrogen peroxide and molecular oxygen [13]. The reduced activity of SOD in liver homogenates of INH-treated mice compared to untreated ones could probably result from induces excessive ROS production, scavenged by SOD. It could be assumed that the antioxidant enzyme SOD could convert the produced highly reactive $\left(\mathrm{O}_{2}^{--}\right)_{x}$ to less reactive species and as a result, the activities of the enzyme in the treated mice decreased. This is the first step of the antioxidant defense against oxidative stress [13]. It is also possible that SOD reduction in treated mice could increase ${ }^{\circ} \mathrm{OH}$ production and thus, to induce lipid peroxidation. SOD activity was amended when INH was administered in combination with SH11.

The observed decrease of SOD and CAT in mice treated with INH might be due to both the additional depletion of antioxidant enzyme system by newly produced ROS and other free radicals during the INH metabolism. The decreased activities of SOD and CAT observed in INH treated mice was probably due to the interaction of the accumulated free radicals with the associated metal ions or with the active amino acids of these enzymes. During hepatotoxicity these enzymes are structurally and functionally impaired by free radical resulting in liver damage [14]. Our results showed that after administration of INH in combination with SH11 the levels of MDA (Figure 6) were decreased and the activities of the antioxidant enzymes SOD (Figure 7) and CAT (Figure 8) were amended. Bearing in mind the excellent expressed SSA activity, higher tuberculostatic activity and lower toxicity of the isonicotinoylhydrazone SH11 [5] and the other results from the present study, we assumed that the combination of INH with SH11 could decrease the hepatotoxic side effects of INH by scavenging $\left(\mathrm{O}_{2}^{--}\right)_{\mathrm{x}}$. Some studies provide information about possible mechanisms by which low antioxidant defense can increase the risk of different associated diseases and promote the progression of the diseases $[15,16]$. Treatment with antioxidants offers protection against hepatotoxicity induced by isoniazid by reducing lipid peroxidation and restoring the antioxidant defense system $[3,6]$.

Our results suggest that there is an increased oxidative stress and disruption of ecological oxidative balance (EOB) in mice treated with INH. In a state of impaired EOB and oxidative stress, biological systems are not protected by oxidative radical influences and these results in toxicity of the organism [17]. After treatment with the combination INH + SH 11, MDA-a marker of radical damage, was reduced, the levels of antioxidant enzymes SOD and CAT in liver were amended, probably after restoration of EOB.
It should be mentioned that the simple singlet EPR signal could be recorded at any time in the powder and solution forms of SH11. At this stage it is impossible to explain the exact type of the radicals registered. Having in mind the result from NMR spectrum of SH11 (Figures 2 and 3) which confirmed the presence of phenolic group in the structure of SH11 (Figure 1) we suppose this group to be involved in formation of these comparatively stable radical species.

\section{CONCLUSION}

In conclusion, it is suggested that EOB, like any other system balance phenomenon, is dynamic and is possible to restore to homeostatic reset with the help of proper ways and means like antioxidant SH11. This first EPR spectroscopy study characterizes Schiff Base SH11 as a new synthetic antioxidant with a good both tuberculostatic and hepatoprotective activities. It could be suggested that the dosage regimen, comprising a combination of INH (at lower doses) and SH11, would decrease the INH-induced oxidative hepatotoxicity/oxidative stress and would be a beneficial approach to tuberculosis treatment.

\section{ACKNOWLEDGEMENTS}

This work was supported financially by the Project No. 02/11 "Investigation of spin-trup activity of xenobiotics by EPR spectroscopy”, Faculty of Veterinary Medicine, Trakia University, Stara Zagora, Bulgaria.

\section{REFERENCES}

[1] Mahesh, C., Shailesh, P. and Mitesh, J. (2010) Recent development and future perspective of antitubercular therapy. Anti-Infective Agents in Medicinal Chemistry (Formerly Current Medicinal Chemistry-Anti-Infective Agents), 9, 59-103. doi:10.2174/187152110791383779

[2] Van Halsema, C.L., Fielding, K.L., Chihota, V.N., Russell, E.C., Lewis, J.J., Churchyard, G.J. and Grant, A.D. (2010) Tuberculosis outcomes and drug susceptibility in individuals exposed to isoniazid preventive therapy in a high HIV prevalence setting. AIDS, 24, 1051-1055. doi:10.1097/QAD.0b013e32833849df

[3] Ravi, V., Patel, S.S., Verma, N.K., Dutta, D. and Saleem, T.S.M. (2010) Hepatoprotective activity of Bombax ceiba linn against isoniazid and rifampicin-induced toxicity in experimental rats. International Journal of Applied Research in Natural Products, 3, 19-26.

[4] Hearn, M.J., Cynamon, M.H., Chen, M.F., Coppins, R., Davis, J., Kang, H.J., Noble, A., Tu-Sekine, B., Terrot, M.S., Trombino, D., Thai, M., Webster, E.R. and Wilson, R. (2009) Preparation and antitubercular activities in vitro and in vivo of novel Schiff bases of isoniazid. European Journal of Medicinal Chemistry, 44, 4169-4178. doi:10.1016/j.ejmech.2009.05.009

[5] Georgieva, N. and Gadjeva, V. (2002) Isonicotinoyl-hydrazone analogs of isoniazid: Relationship between super- 
oxide scavenging and tuberculostatic activities. Biochemistry (Moscow), 67, 588-591.

doi:10.1023/A:1015558514432

www.ncbi.nlm.nih.gov/pubmed/12059780

[6] Georgieva, N., Gadjeva, V., Tolekova, A. and Dimitrov, D. (2005) Hepatoprotective effect of isonicotinoylhydrazone SH7 against chronic isoniazid toxicity. Die Pharmazie, 60, 138-141. www.ncbi.nlm.nih.gov/pubmed/15739904

[7] Varbanova, S. and Georgieva, N. (1993) New isonicotinoylhydrazones with tuberculostatic action. Veterinary Science, 27, 81-85.

[8] Geran, R.S., Greenberg, N.H., Macdonald, M.M., Schumacher, A.M. and Abbott, B.J. (1972) Protocols for screening chemical agents and natural products against animal tumors and other biological systems. Cancer Chemotherapy Reports, 13, 1-87.

[9] Lowry, O.H., Rosenbrough, N.J., Farr, A.L. and Randall, R.J. (1951) Protein measurement with the Folin phenol reagent. The Journal of Biological Chemistry, 193, 265275. www.ncbi.nlm.nih.gov/pubmed/14907713

[10] Placer, Z.A., Cushman, L.L. and Jonson, B.C. (1966) Estimation of product of lipid peroxidation (malonyl dialdehide) in biochemcal systems. Analitical Biochemistry, 16, 359-364. doi:10.1016/0003-2697(66)90167-9

[11] Sun, Y., Oberley, L.W. and Li, Y. (1988) A simple method for clinical assay of superoxide dismutase. Clinical Chemistry, 34, 497-500.

\section{ABBREVIATIONS}

$\mathrm{CAT}=$ Catalase

DMSO $=$ Dimethylsulfoxide

$\mathrm{EPR}=$ Electron paramagnetic resonance

$\mathrm{INH}=$ Izoniazid

$\mathrm{LD}_{50}=$ Lethal dose

MDA $=$ Malondialdehyde

$\mathrm{MIC}=$ Minimum inhibitory concentration

$\mathrm{NBT}=$ Nitroblue tetrazolium

PBS $=$ Phosphate buffered saline
[12] Beers, R. and Sizer, T. (1952) Spectrophotometric metod for measuring the breakdown of hydrogenperoxide by catalase. The Journal of Biological Chemistry, 195, 133138.

[13] Fridovich, I. (1975) Superoxide dismutases. Annual Review of Biochemistry, 44, 147-159. doi:10.1146/annurev.bi.44.070175.001051

[14] Bhadauria, S., Mishra, R., Kanchan, R., Tripathi, C., Srivastava, A., Tiwari, A. and Sharma, S. (2010) Isoniazidinduced apoptosis in HepG2 cells: Generation of oxidative stress and Bcl-2 down-regulation. Toxicology Mechanisms and Methods, 20, 242-251. doi: $10.3109 / 15376511003793325$

[15] Afanas'ev, I. (2010) Signaling of reactive oxygen and nitrogen species in diabetes mellitus. Oxidative Medicine and Cellular Longevity, 3, 361-373. doi:10.4161/oxim.3.6.14415

[16] Santhosh, S., Sini, T.K., Anandan, R. and Mathee, P.T. (2007) Hepatoprotective activity of chitosan against isoniazid and rifampicin-induced toxicity in experimental rats. European Journal of Pharmacology, 572, 69-73. doi:10.1016/j.ejphar.2007.05.059

[17] Georgieva, N.V. (2005) Oxidative stress as a factor of disrupted ecological oxidative balance in biological systems-A review. Bulgarian Journal of Veterinary Medicine, 8, 1-11. http://tru.uni-sz.bg/bjvm/vol08-no01-01.pdf

ROS $=$ Reactive oxygen species

SH11 = N-isonicotinoyl-N'-(3-ethoxy-2-hydroxybenzaldehyde)hydrazone

SH7 = N-isonicotinoyl-N'- (3,5-dichloro-2-hydroxybenzal)hydrazone

SOD $=$ Superoxide dismutase

SSA $=$ Radical scavenging activity

TBA $=$ Thiobarbituric acid

TBARS $=$ Thiobarbituric acid-reactive substance 